\title{
APPLICATION OF KNOWLEDGE MANAGEMENT IN CROSS-BORDER MERGERS AND ACQUISITIONS
}

\author{
[Uplatňovanie manažmentu znalostí v medzinárodných fúziách a akvizíciách]
}

\author{
Soňa Ferenčíková ${ }^{1}$, Alena Vícenová ${ }^{2}$ \\ ${ }^{1}$ Vysoká škola manažmentu/City University of Seattle, Panónska cesta 17, 85104 Bratislava \\ E-mail: sferencikova@vsm.sk \\ ${ }^{2}$ Vysoká škola manažmentu/City University of Seattle, Panónska cesta 17, 85104 Bratislava \\ E-mail: avicenova@vsm.sk
}

\begin{abstract}
The purpose of the paper is to look of major integrative processes and trends encountered within cross-border merger and acquisition $(\mathrm{M} \& \mathrm{~A})$; also research into the nature and dissemination possibilities for knowledge management (KM) as a means towards optimization of post-integration synergies. The authors devote a lot of attention to the bearer of tacit knowledge that can not be lost in the cross-border integration processes. The authors emphasize the importance of deepened due diligence, which can capture the cultural and ethical compatibility of potential integration partners, without which planned synergies may not be realized. In the conclusion, the authors calls upon acquisition managers to embark on a more "enlightened" approach to the activities intrusted in their hands, in terms of developing a clear vision of M\&A goals. Clearly, so called "shotgun acquisition marriages" have nothing in common with KM principles. The feverish buying and selling associated with $\mathrm{KM}$, the integration of companies and organizations, complete with their human capital and potential may often shatter the identity and well-being of whole working teams and individual employees.
\end{abstract}

Key words: cross-border mergers and acquisitions, knowledge management.

JEL Classificcation: M16

Doručeno redakci: 28.7.2014; Recenzováno: 1.8.2014; 3.8.2014; Schváleno k publikování: 11.2.2015

\section{Úvod}

Je všeobecne známe, že už začiatkom 20. storočia sa v USA uskutočňovali podnikové operácie patriace do skupiny fúzií a akvizícií (merger and acquisition - M\&A). V tom čase vel'ký počet malých podnikov začal zvažovat' spájanie sa do tzv. trustov, ktorých ciel'om bolo zvýšenie trhového podielu. V súčasnosti už fúzie a akvizície nie sú len doménou americkej ekonomiky, ale stali sa „bežnou súčast'ou rastovej stratégie spoločností po celom svete“ Spodniak, Cesnak (2010). Môžeme povedat', že fúzie a akvizície sa stali kl'účovou súčast'ou stratégie korporácií, zameranou predovšetkým na dosiahnutie synergického efektu v rozličných oblastiach podnikatel'ských aktivít.

Všeobecne platí, že rast v oblasti medzinárodných fúzií a akvizícií bol poháňaný túžbou spoločností zvýšit' ich konkurencieschopnost'. To sa odohráva v prostredí rastúcej simultánnej fragmentácie a globalizácie trhov, rýchleho tempa zmien a odstraňovania colných bariér $\mathrm{v}$ celosvetovom meradle. Také prostredie je prirodzene hnacím motorom rastu vel'kých firiem a kombinácií rôznych priemyselných odvetví Ferenčíková (2013).

V súčasnosti globálny svet je čoraz otvorenejší a pôsobí takmer jednoliato, ale na druhej strane doznievajúca celosvetová ekonomická kríza poučila akvizičných manažérov, že štrukturálne a kultúrne rozdiely medzi krajinami musia byt' zohl'adňované. Akvizičný paradox (ktorý znamená, že iba málo akvizícií a fúzií dosiahne stanovené ciele) znamená, 
že je potrebné venovat' čoraz väčšiu pozornost' nositel'om tacitných znalostí, ktoré sa nesmú stratit' v cezhraničných integračných procesoch. Ide o prvý pokus inkorporácie problematiky znalostného mamažmentu do oblasti medzinárodného podnikania, konkrétne problematiky riadenia cezhraničných fúzií a akvizícií v slovenskej lietratúre. Cielom tohto príspevku je navrhnút' možnosti rozšírenia aplikácie manažmentu znalostí ako nástroja optimalizácie postintegračných synergií $\mathrm{v}$ cezhraničných fúziách a akvizíciách. Ciel’om nášho výskumu, prostredníctvom kvalitatívneho výskumu, ktorý predpokladá nenumerické bádanie a interpretáciu spoločenskej reality, je vytváranie nových hypotéz a teórií, v prvom rade prostredníctvom analýzy textov, ktorá má zabezpečit' porozumenie skúmaných javov. Okrem toho, kvalitatívny výskum je rozborom, ktorý napomáha popisu a nejednoznačných fenoménov l'udského života a študuje danú realitu híbkovo a podrobne, a preto sme siahli po jeho metódach v nami skúmanej hraničnej oblasti.

\section{Teoretické východiská skúmanej problematiky}

Vo svete nie je jednotne zadefinovaný pojem spojenia firiem. Vo vedeckej a odbornej literatúre sa stretávame s rôznymi definíciami tohto konceptu. Niektorí autori vo svojich knihách označujú všetky spojenia firiem pojmom „fúzia“. Iná skupina autorov definuje fúziu iba ako jednu z foriem spájania firiem, a ešte d’alší následne rozlišujú pojmy „konsolidácia“ a „akvizícia“. Ale sú i takí autori, ktorí hovoria o fúzii, ak prichádza k dobrovol'nému spojeniu firiem, kým nedobrovol'ná integrácia sa označuje ako „prevzatie“ (takeover). Novým vnímaním pojmu je úplné oddelenie fúzií od akvizícií, to znamená že sa nepoužíva jednotné označenie fúzia a akvizícia (M\&A). Konkrétnejšie, pojem „fúzia“ sa používa, ked” „dve spoločnosti majú podobnú vel'kost' v zmysle počtu zamestnancov alebo vo výške obratu“ Jasimuddin (2012). Pojem „akvizícia“ sa používa vtedy, ked’,,jeden z partnerov je ovel’a väčší ako druhý“ Jasimuddin (2012). Jasimuddin argumentuje, že pri akvizícii „kupujúca spoločnost' prevezme kontrolu nad kupovanou, a tá stráca ekonomickú a právnu autonómiu“, zatial’ čo pri fúzii „dve alebo viaceré spoločnosti vytvárajú nový subjekt“ (2012). Navyše, fúzia sa odohráva prostredníctvom dohody medzi dvomi organizáciami v priatel'skom prostredí, akvizícia sa uskutočňuje v nepriatel'skom. Rozdielnost' v ponímaní týchto pojmu nevychádza iba $z$ rôzneho chápania jednotlivých autorov, ale vychádza i z rozdielnosti jednotlivých právnych noriem vo svete Baláž et al. (2005), Ferenčíková et al. (2013), Šaková (2004).

Fúzie a akvizície úzko súvisia so znalostným manažmentom alebo manažmentom znalostí (v originálnej anglickej terminológii sa oba tieto pojmy zlievajú do jedného názvu, a to knowledge management). V roku 1993 P. F. Drucker predpovedal nutnost' riadenia znalostí, nebol však rozhodne prvý. Japonský konzultant Kenichi Ohmae konštatoval, že nová, rodiaca sa ekonomika bude založená na znalostiach. Ešte pred ním však prišiel s tvrdením Fridrich von Hayek, že najdôležitejším aktívom spoločnosti je jej schopnost' pracovat' so svojimi vedomost'ami. Drucker však odhalil podstatu a položil si otázky: Ako kvalifikovat' znalosti? Kol'ko stojí vyprodukovanie a distribuovanie znalostí? Ako možno vôbec rozumiet' výrazu „návratnost' znalostí? Drucker hovoril o znalostiach ako zdrojoch, ktoré budú v budúcnosti vel'mi dôležité. Rozoznával tri druhy, a to zdokonal'ovanie postupov, výrobkov a služieb; exploatácia, nepretržité využívanie existujúcich znalostí k vytváraniu nových, rozdielnych výrobkov, postupov a služieb; a posledné, skutočné inovácie teda uplatnenie znalostí k produkcii nových znalostí. Otázky, ktoré sformuloval Drucker boli pre podnikatel'skú oblast' nezrozumitel'né, ale ako sa neskoršie ukázalo životne dôležité. O dva roky neskoršie vyšla práca Ikujira Nonaky a Hirataky Takeuchiho, ktorá naštartovala vel'ký záujem o manažment znalostí Truneček (2004). 
V súčasnosti autor Jasimuddin definuje manažment znalostí ako „spôsob, ktorý pomáha zvýšit' udržatel'nú konkurenčnú výhodu organizácie“" (2012). Je treba poznamenat', že so zvyšujúcim sa tlakom konkurenčného prostredia sa podniky začínajú orientovat' na interné faktory, ktoré posilnia ich konkurenčnú pozíciu, čím sa do popredia dostáva udržatel'nost' konkurenčnej výhody. Práve komponentom udržatel'nosti sú inovácie. Ako uvádzajú Miklošík, Hvizdová, Žák inovácie posúvajú „firemnú podnikatel’skú stratégiu $\mathrm{k}$ tvorbe novej hodnoty pre zákazníka. Inovácia ako aplikovatel'né inovatívne myslenie, ktoré ovplyvňuje podnikatel'skú činnost', je spôsobom hladania zmeny pravidiel konkurenčného boja“ (2012). Vo vzt'ahu k inováciách, manažment znalostí vychádza z predpokladu, že ,schopnost' inovovat' výrobky a služby bude klúčovou kompetenciou vtedy, ak podniky budú schopné inovovat' samých seba zvnútra, ide teda o vnútornú inováciou jednotlivcov, ktorú možno chápat' ako neustálu potrebu nových znalostí, zručností, závislých od schopností jednotlivcov. Efektívne využívanie znalostí prispieva k pozitívnemu stimulu inovačnej kapacity a k trvalo udržatel'nému rozvoju podniku. Znalosti, t.j. schopnosti a um jednotlivcov, sú v súčasnom období pre podniky najdôležitejšia forma kapitálu“ Miklošík, Hvizdová, Žák (2012).

V pôvodnej slovenskej literatúre Kelemen definuje manažment znalostí ako „systematický proces vyhl'adávania, výberu, organizácie, koncentrácie a prezentácie poznatkov, znalostí spôsobom, ktorý napomáha v organizáciách zvyšovat' úroveň, na akej zamestnanci rozumejú konkrétnym oblastiam.“ To znamená, manažment znalostí pomáha organizáciám dosahovat' hlbší pohl'ad a porozumenie najmä na základe využitia skúseností a intelektuálneho imania pracovníkov. Úlohou manažmentu znalostí je napomôct' organizáciám, aby získavali, uchovávali, ale i vymieňali si znalosti svojich zamestnancov, a hlavne, aby ich využívali pri rozhodovaní, plánovaní vo svojich organizáciách a tým posúvali ich na rastovú trajektóriu. Manažment znalostí nie je teda „technológiou samou osebe, ani súborom najlepších postupov, ale je stavom mysle, teda prístupom, ktorý sa musí rozšírit' v rámci celej organizácie, ak má byt' úspešný“' Kelemen et al. (2007).

V spojitosti s fúziami a akvizíciami manažment znalostí definujeme ako „systematickú koordináciu l’udí, technológií a procesov v organizácii, výmeny a aplikácie znalostí. Znalosti, ktoré sú získavané zvonka ale aj zvnútra organizácie by sa mali podchytit' a vytvárat' organizačnú pamät', ktorá by mala podporovat' trvalé organizačné učenie“ Vícenová (2013).

Pre uskutočnenie cezhraničných fúzií a akvizícií, ked' ide aj integráciu rôznych kultúr, je vel'mi dôležité mat' na zreteli štruktúru znalostí, aby sme predišli ich strate pri vytváraní nových pracovných tímov. V tomto kontexte sa najčastejšie stretávame s delením znalostí na tacitné (z ang. tacit) a na explicitné (zjavné) znalosti. Tacitné znalosti sa nachádzajú v hlavách - v mysliach pracovníkov v organizácii. Sú to neformalizované znalosti, ktoré je vel'mi t'ažko zachytit' v presných popisoch alebo tabul'kách Kelemen et al. (2007). Tacitná znalost' je vždy viazaná na človeka či skupinu l'udí s ich činnost'ami, postupmi, rutinami, ideami, nápadmi, hodnotami a emóciami. Tacitné znalosti predstavujú vel'ký potenciál pre spoločnosti, nakol'ko sú životne dôležité pre fungovanie a dlho sa získavajú. Naopak, explicitné znalosti je možné relatívne l'ahko formalizovat', zaznamenávat', zdiel'at' pomocou jazyka, obrázkov, písma, formulácií, špecifikácií alebo inými informačnými nástrojmi Mládková (2005). V literatúre sa stretávame ešte s jedným typom znalostí, a to implicitná znalost'. Implicitná znalost' je „uložená v hlavách pracovníkov, avšak nie je l'ahké alebo ani dokonca možné ju kedykol'vek previest' do explicitnej formy, formalizovat' ju či dokumentovat"“ Bureš (2007). 
Aké sú explicitné a tacitné znalosti v medzinárodných fúziách a akvizíciách? Medzinárodné fúzie a akvizície kombinujú integráciu fyzických aktív, organizačných procesov a l'udí. Explicitné znalosti sa skladajú z technickej a organizačnej inteligencie, porozumenia a metód, ktoré môžu byt' l'ahko kodifikované a dostupné prostredníctvom verbálnej alebo písomnej komunikácie. Taktiež, explicitné znalosti môžeme asociovat' s fyzickými a organizačnými procesmi. Naopak, tacitné znalosti obsahujú odborné znalosti a zručnosti, ktoré sú založené na podchytených a akumulovaných skúsenostiach. Sú uchované v mysliach jednotlivcov Stahl \& Mendenhall (2005).

Tacitná a explicitná znalost' je kultúra, norma a hodnota, ktorá vedie resp. riadi organizáciu. Napríklad produkty často vedú k inovácii a rýchlejšiemu prístupu na trh. Na druhej strane, organizačné procesy reflektujú normy informačných výmen medzi firmami, ktoré veria, že táto interakcia zlepší ich kvalitu produktov na trhu. Napokon l'udia stelesňujú kultúru a to takým spôsobom, že pracujú a rutinne spolupracujú jeden s druhým používajúc normy a hodnoty, ktoré ich vedú k rozhodovaniu, komunikácii a iným činnostiam pri rozvoji, výrobe a predaji produktov Stahl \& Mendenhall (2005).

\section{Manažment znalostí a bezpodmienečné poznanie}

Samotná definícia implicitnej znalosti naznačuje, akou vel'kou výzvou je zachovanie tohto typu znalosti a jeho prevedenie do explicitnejších foriem. Netreba ani zdôrazňovat', akým zranitel'ným sa stáva tento typ znalosti $\mathrm{v}$ cezhraničných procesoch, najmä kvôli často nedbalej a nedomyslenej politike reštrukturalizácie a prepúšt'ania. Pre možnosti vypracovania efektívnejšieho spôsobu zachovania znalostí, a tým aj prekonania niektorých deficitov v systéme manažmentu znalostí, pozrieme sa na ešte jednu možnú kategorizáciu znalostí, ktorá by mohla napomôct' $\mathrm{k}$ optimálnejším postojom k l’udskému kapitálu v akvizičných procesoch. Ide o kategorizáciu poznania navrhnutú J. Hvoreckým. Podl’a neho najmenšou čiastkou nášho poznania je tzv. bezpodmienečné poznanie (unconditional) alebo „kategorické“ poznanie. Jednoduchšie povedané, je to čisté, „tvrdé“ poznanie (hard knowledge), ktoré nepodlieha spochybneniu a všetkými sa považuje za pravdivé/správne. Takéto jadro vytvárané bezpodmienečným poznaním je prítomné aj v rámci d’alších kategórií, a to tzv. zdôvodneného alebo dokázaného poznania (justified knowledge), a nakoniec sú to poznatky, ktorým veríme bez dôkazov (believed knowledge) Hvorecký (2013).

\section{Obrázok 1: Úroveň l'udských znalostí}

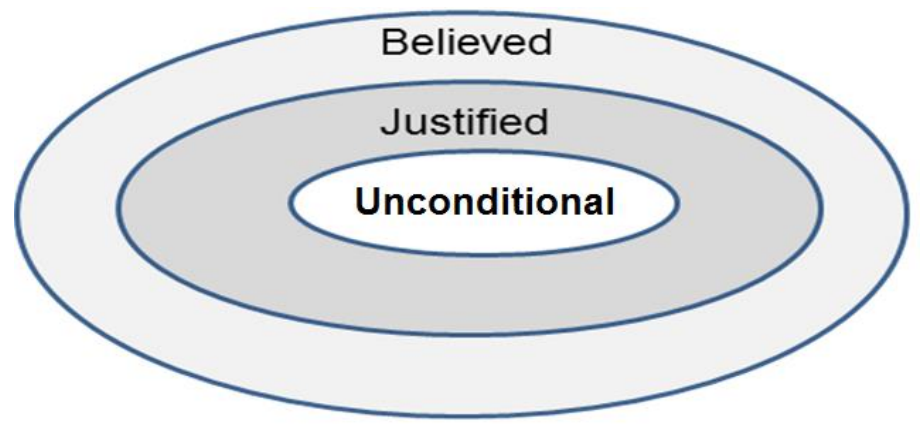

Zdroj: Hvorecký (2013)

Pre prax je obzvlášt' dôležité, že takéto kategorické poznanie sa dá spracovávat', uschovávat' a prenášat' aj pomocou informačno-komunikačných technológií (ICT). Treba povedat', že z čisto vedeckého hl'adiska, len bezpodmienečné poznanie je správne. Ale s tým nemusia 
súhlasit' napr. manažéri, pretože podl'a ich názoru aj tzv. zdôvodnené poznanie (justified knowledge) a poznanie, ktorému veríme (believed knowledge), majú vel'kú úlohu v rozhodovacích procesoch. (Obrázok 1) Tiež nezabúdajme, že pre prax je vel'mi dôležitá tzv. konsensuálna pravda, kde správnym je to, na čom sme sa dohodli pre dobro podniku.

Dôsledky neriešených rozdielov v kategórii poznania, v ktoré „veríme“, sa môžu stat’ zdrojom konfliktov a niekedy aj vyslovenej disfunkcie na určitých pracoviskách. Manažér vybavený princípmi manažmentu znalostí, vrátane komplexného pochopenia štruktúry poznatkov, si musí v takejto situácii plne uvedomit', že nie všetko poznanie je „racionálne“, pretože takmer vždy je ovplyvňované bud' tradíciou alebo jednoducho vierou. Manažér musí byt' seizmograficky citlivý k prejavom a ukážkam takého „nevedeckého“ poznania, a byt' schopný využit' „iracionálne vrstvy poznania a intuície“ na riešenie nejednoznačných komplexných javov, najmä v podmienkach časovej tiesne a stresu, čo je aj prípad medzinárodných fúzií a akvizícií Hvorecký (2013).

Nedostatok kompatibility medzi rôznymi kategóriami znalostí sa môže stat' zdrojom viacerých problémov. Pod kompatibilitou sa rozumie a) schopnost' existovat' a fungovat' v harmonickej súhre; b)schopnost' usporiadanej, efektívnej integrácie a pôsobenia s inými prvkami systému bez potreby modifikácie alebo konverzie Hvorecký (2013). Ako vidíme, tá druhá charakteristika kompatibility je bezprostredne spätá s ruptúrami v ekonomickospoločenských procesoch, ktoré sprevádzajú najmä cezhraničné fúzie a akvizície.

V praxi to znamená, že od členov integračných tímov zodpovedných za realizáciu medzinárodných fúzií a akvizícií sa očakáva schopnost' zjednotených postupov a viac menej súhlasná interpretácia ich výsledkov. Ked’ ide o iracionálnejšie kategórie poznania, pre ich dostupnú štandardizáciu a lepšiu využitel'nost' sa musíme opierat' o zjednotený systém pojmov a metód. V ideálnych situáciách takto dosiahnutá kompatibilita môže prekračovat' steny podniku, čím sa premostí „nechápanie“ medzi podnikovým poznaním a jeho širším okolím. Čo sa týka kategórie poznania ako viery (believed knowledge), len môžeme súhlasit' s tvrdením, že rozdiely v názoroch prenášané na pracovisko negatívne dopadajú na efektívnost' práce. Dobrým riešením môže byt' stanovenie filozofie a stanoviská podniku, ktoré, ak nevyhovujú jednotlivým pracovníkom, nemusia sa uplatňovat' $v$ ich súkromnom živote, ale nedodržanie stanovených princípov na pracovisku by malo znamenat' vylúčenie z tímu Hvorecký (2013).

\section{Manažment znalostí a nemenej formalizovatel'né druhy poznania}

Kombinácia informačno-komunikačných technológií (ICT) a manažmentu znalostí je „,bránou, ktorá vedie k racionálnemu prístupu k riadeniu“. Treba však pripomenút', že takéto očakávania sa v prvom rade vzt’ahujú na explicitné poznanie, ktoré je vhodné pre spracovanie pomocou ICT. Určitou výzvou, ale zároveň i príležitost'ou však zostáva využitie tacitného, „nie dost' rigorózneho“ poznania, ktoré patrí k formám „,iracionálneho“ poznania. Iracionalita totiž nemusí byt' chápaná ako opak racionality. V zmysle princípov manažmentu znalostí môžeme chápat' iracionalitu ako pozitívny zdroj podvedomého poznania, intuícií, kladných emócií a napomáhajúceho poznania založeného na viere, čím by sme nemali mrhat'. Iracionalita je prírodná a legitímna súčast' l'udskej povahy a v tomto zmysle je primárne pozitívna. Je úlohou manažmentu znalostí využit' túto zanedbanú studňu. Taktiež povinnost'ou manažéra je zabezpečit', najmä na novovytvorenom pracovisku, cirkuláciu edukačných a socializačných procesov, ktoré napomáhajú externalizácii a následnej internalizácii „mäkších“ foriem znalostí Hvorecký \& Lichardus (2012). 
Je dôležité si uvedomit', že na zvládnutie a riadenie tzv. iracionálnych častí poznania manažéri musia aplikovat' iné zručnosti ako tie, ktoré používajú na riadenie racionálneho poznania. Metódy identifikácie, zachovania a rozvíjania iracionálneho poznania sú nutne „menej priamočiare" a viac sa zakladajú na kooperácii medzi manažérom a jeho tímom. Inými slovami, manažment znalostí sa nevyhne širšiemu pohl'adu na podnikovú organizáciu, organizačnú štruktúru a tradičné hierarchie vertikálneho rozkazovania. Pokročilý manažment znalostí vyžaduje od manažérov aj schopnost' selektovania príslušných pracovníkov na pozície „znalostných“ zamestnancov. Ide o to, že kritérium vzdelanosti ako tvrdé racionálne kritérium nie je postačujúce $\mathrm{v}$ zmysle komplexnejšieho prístupu k povahe a cirkulácii poznania. Znalostný pracovník okrem iného musí tiež mat' záujem o svoju profesiu a byt' motivovaný spolupracovat' a odovzdávat' svoje poznatky. „Užitočná iracionalita“ znalostných pracovníkov musí byt' mapovaná a efektívne aplikovaná pre zabezpečenie úspešných podnikových aktivít, vrátane akvizičných a najmä ked' ide o cezhraničné akvizície, kde výzvou sú rozdielne jazyky a kultúry. Manažment znalostí môže realizovat' svoj potenciál a priniest' očakávané ovocie len za podmienky mnohoúrovňového chápania štruktúry znalostí a z toho nutne vyplývajúcich nových manažérskych zručností a metód pre vybudovanie znalostne kompatibilných tímov Hvorecký \& Lichardus (2012).

\section{2 Úloha manažmentu znalostí v cezhraničných fúziách a akvizíciách}

Zatial' iba vel'mi málo vedcov spracovalo úlohu manažmentu znalostí v medzinárodných fúziách a akvizíciách preto sa budeme zaoberat' ponímaním úlohy manažmentu znalostí v medzinárodných fúziách a akvizíciách, a to pohl'adom do odbornej literatúry. Jedným z prvých autorov je Sajjad M. Jasimuddin, ktorý tvrdí, že táto oblast' má rastúcu tendenciu. Jednou z výhod manažmentu znalostí je napríklad, že má „tendenciu zvyšovat' výkonnost' organizácie pomocou využitia existujúcich znalostných aktív" (Jasimuddin, 2012). V tejto súvislosti autor vyzýva $\mathrm{k}$ lepšiemu využívaniu firemných znalostí. Svoje tvrdenie podporuje tým, že manažment znalostí môže firme zabezpečit' dostupnost' „správnych znalostí správnym l'ud'om v správny čas“ Jasimuddin (2012). Autor upozorn̆uje na možnost' „vytvárania nových nápadov, lepšie využitie organizačnej moci myslenia, podporu inovácií, zachytávanie nových postrehov a skúsenosti, aby boli k dispozícii vtedy, kedy, kde a kým budú požadované, podporu spolupráce a zdiel'anie vedomostí“. Ďalej dodáva, že vedci skúmajúci medzinárodné fúzie a akvizície navrhujú, že znalosti z obidvoch kombinovaných spoločností by mali byt' považované za životne dôležité, a to z toho dôvodu, že vel'mi silne ovplyvňujú aktivitu v oblasti fúzií a akvizícií. V kontexte fúzií a akvizícií môže príst' ku strate podnikových zdrojov - znalostí. Práve odborníci najčastejšie varujú pred stratou tacitných znalostí, ktoré sú budované na skúsenostiach l'udí v organizáciách. Kupujúca spoločnost' musí zvládnut' podchytenie znalostí počas zmien v organizačnej štruktúre a kultúre. Jasimuddin (2012)

Uskutočnenie fúzie a akvizície predstavuje jedno z najdôležitejších strategických rozhodnutí vo firmách. Každé rozhodnutie má dlhotrvajúce následky pre skombinované firmy a predstavuje hrozbu pre ich prežitie. Prostredníctvom fúzií a akvizícií sa môže firma dostat' k nových zručnostiam, technológiám a produktom, ale je tu však i možnost' straty firemných znalostných zdrojov. Autor Jasimuddin opisuje, že existujú rozdielne scenáre fúzií a akvizícií, ktoré sú založené na tom, či manažment znalostí je bežnou praxou v obidvoch spoločnostiach už pred aktivitou spojenia alebo skúpenia firmy. V prvej situácii obidve spoločnosti /nazvime ich jednoducho spoločnost' A a spoločnost' B) aplikujú prístup manažmentu znalostí; v druhej situácii - iba spoločnost' A uplatňuje manažment znalostí, v tretej situácii spoločnost' A si neuplatňuje manažment znalostí a v poslednej štvrtej situácii ani jedna spoločnost' nepracuje na princípoch manažmentu znalostí pred integráciou. 
Tabul'ka 1: Rozdielne scenáre pre fúzie a akvizície zohl'adňujúce manažment znalostí

\begin{tabular}{|l|lcl|l|}
\hline Situácia & $\begin{array}{l}\text { Uplatňovanie manažmentu znalostí } \\
\text { v prípravnej fáze }\end{array}$ & $\begin{array}{l}\text { Skombinová firma po fúzii alebo } \\
\text { akvizícii }\end{array}$ \\
\hline & A Spoločnost' & B & Áno & $\begin{array}{l}\text { Záleží na integrácii - ale nie je to } \\
\text { zložité }\end{array}$ \\
\hline I & Áno & Áno & Zložitá integrácia \\
\hline II & Áno & Nie & $\begin{array}{l}\text { Zložitá integrácia vzhl'adom na slabšiu } \\
\text { pozíciu kupovaného }\end{array}$ \\
\hline III & Nie & Áno & $\begin{array}{l}\text { Náročná úloha - je potrebné zaviest' } \\
\text { manažment znalostí od začiatku }\end{array}$ \\
\hline IV & Nie & Nie &
\end{tabular}

Zdroj: autorky, Jasimuddin (2012)

Výsledok výskumu je, že obe spoločnosti, ak uplatňovali manažment znalostí nenarážajú na t'ažkosti počas kombinovania, ale samozrejme, záleží na spôsobe, akým bude uskutočnená. V druhej situácii, kedy iba jedna firma uplatňuje manažment znalostí ešte pred uskutočnením prípravnej fázy, predpokladá sa, že integrácia bude st’ažená. $V$ tretej situácii je to komplikovanejšie, o to, o čo je slabšia pozícia firmy B ako nadobúdanej (zvyčajne firma A ako kupujúca diktuje podmienky integrácie). Vo štvrtej situácii, kedy ani jedna zo spoločností neuplatňovala princípy manažmentu znalostí pred integráciou, predpokladá sa, že integrácia bude vel'mi náročná. Záverom výskumu je odporúčanie zapojit' manažment znalostí už v úvodných fázach podnikového kombinovania alebo skupovania.

Príkladom úspešnej akvizície /aj druhej situácie/ so zapojením manažmentu znalostí je medzinárodná akvizícia Sanofi-aventis, ktorá kúpila spoločnost' Zentivu na slovenskom farmaceutickom trhu. Spoločnost' nezanedbala žiaden z detailov predakvizičnej fázy, za čo sčasti vd'ačí za svoj úspech. Nezanedbatel'ným faktorom úspešnosti danej kombinácie je starostlivé vytvorenie nového manažérskeho zoskupenia, kde kvôli zachovaniu kontinuity nejaký čas pretrvávali vedúci pracovníci ciel’ového podniku vo svojich pozíciách. Zásadnou otázkou pri cezhraničných fúziách a akvizíciách je, ako zachovat' tacitné (implicitné) znalosti, kvôli ktorým sa často tieto operácie uskutočňujú, a ktoré môžu najpodstatnejším spôsobom ovplyvnit' ich celkový úspech alebo neúspech. Sanofi-aventis sa podarilo zachovat' talenty a nestratit' nič z tacitného poznania. Medzi viacero rozhodujúcich faktorov bolo správne vyhodnotenie ciel'ovej spoločnosti, rozšírená due diligence, vrátane kultúrnych faktorov, a napokon zabezpečenie jasnej komunikácie a vízie do budúcnosti. Taktiež nutnost' presného plánovania jednotlivých krokov na všetkých fázach (ako je prípravná, due dilligence, realizačná a porealizačná), zabezpečenie udržania kl’účových pracovníkov ako zdroja tacitného poznania. Manažment znalostí v cezhraničných fúziách a akvizíciách nie je len vonkajšou dekoráciou, ale reálnou silou a zárukou akvizičného úspechu. Zohl’adnenie a zdôraznenie l'udské faktora, ktorý je v centre filozofie manažmentu znalostí sa stal požiadavkou podnikových zlúčení Vícenová (2013).

Osobitnou výzvou pre medzinárodné fúzie a akvizície je však správne riadenie znalostných aktív, ktoré prechádzajú z obidvoch jednotiek sústredených už v skombinovanej spoločnosti. Dlhodobo pretrváva názor, že aktivity v oblasti medzinárodných fúzií a akvizícií vytvárajú klímu strachu a straty dôvery medzi zamestnancami dvoch jednotiek, ktoré majú splynút', čo môže skomplikovat' zdiel'anie a prenos znalostí. Môže príst' k odchodu expertov z kúpenej spoločnosti, zničeniu získanej organizačnej znalostnej „ekológie“, neadekvátnemu 
pochopeniu získaných firemných znalostí a v niektorých prípadoch dokonca aj $\mathrm{k}$ ich zániku (v dôsledku odchodu ich nositel'ov alebo nesprávnej integrácie).

\section{Aktualizácia problematiky v nových podmienkach - , The New M\&A Playbook”}

Po celé stáročia sa ekonómovia a podnikatelia zaoberali sledovaním rastu spoločností. Ich spojené úsilie bolo podporené lepším pochopením zdrojov a prostriedkov smerujúcich k hospodárskemu rastu, čoho príkladom sú fúzie a akvizície. Ďalší, ktorí analyzujú problematiku medzinárodných fúzií a akvizícií v spojitosti s manažmentom znalostí sú autori článku The New M\&A Playbook z marca 2011 v Harvard Business Review. Autori Christensen, Alton a Rising sa pustili do hlbšej analýzy prebiehajúceho javu upozornuujúc akvizičné tímy na viac aspektov v jednotlivých fázach a očakávaných synergiách. Podl'a nich sa každodenne sa kupujú nesprávne spoločnosti za nesprávnym účelom, nesprávne ohodnotené a nesprávne prvky sa integrujú do nesprávnych obchodných modelov. Mnoho „nesprávneho“ ich inšpirovalo bližšie sa pozriet' na procesy v oblasti fúzií a akvizícií s ciel'om pomôct' generálnym riaditel'om predpovedat' s väčšou presnost'ou, či firma v ponuke je „vysnívaná“ alebo to bude d’alší „debakel“ Christensen et al. (2011).

Ked' chce generálny riaditel' zvýšit' firemnú výkonnost' a naštartovat' dlhodobý rast prostredníctvom kúpy inej spoločnosti, možno to považovat' za mimoriadne: firmy každoročne vynakladajú viac ako 2 trilióny amerických dolárov na akvizície. Napriek tomu, štúdie za štúdiou dokazujú, že miera zlyhávania fúzií a akvizícií (akvizičný paradox) sa pohybuje v rozmedzí $70 \%$ až 90\%. Mnoho vedcov sa snaží vysvetlit' tieto bezútešné štatistiky obvykle na základe analýzy atribútov obchodov, ktoré fungovali a ktoré nie. Autori článku sa pokúsili poskytnút' robustnejšiu teóriu, ktorá identifikuje príčiny týchto spomínaných úspechov a neúspechov.

Vychádzajú z toho, že vel'a akvizícií nesplńa očakávania, pretože manažéri nesprávne zadelia kandidátov k strategickému ciel’u obchodu, zlyhávajú pri rozlišovaní medzi obchodmi, ktoré môžu zlepšit' existujúcu činnost' a tými, ktoré by mohli dramaticky premenit' spoločnost' na rastovú. V dôsledku toho firmy vel'mi často platia nesprávnu cenu a integrujú ciel'ovú spoločnost' nesprávnym spôsobom. Jednoducho povedané existujú dva dôvody prečo sa snažit' získat' inú firmu. Prvým, najbežnejším dôvodom je zvýšenie podnikovej výkonnosti, ktorá, na jednej strane, pomôže udržat' prvotriedne pozície, ale, na strane druhej, zníži náklady. Akvizícia, ktorá prinesie tieto výhody takmer nikdy nezmení „trajektóriu“ spoločnosti. Druhým, menej známym dôvodom je nové vytvorenie obchodného modelu čím prichádza $\mathrm{k}$ základnému presmerovaniu spoločnosti. Len málo $\mathrm{z}$ vedúcich manažérov rozumie tomu, ako identifikovat' najlepšie ciel'ové podniky $\mathrm{k}$ dosiahnutiu svojej vízie, kol'ko za ne zaplatit' a ako ich správne integrovat'.

Prakticky povedané, najprv sa spýtajme: Čo kupujeme? Dá sa povedat', že úspech a aj neúspech akvizície závisí od dobrých základov integrácie. Najistejšou cestou k úspechu je rozmýšl'at' o ciel'ovej spoločnosti v zmysle obchodného modelu. Obchodný model pozostáva zo štyroch nezávislých elementov, ktoré vytvárajú a prinášajú hodnotu.

1. Prvým je zákaznícka hodnota: ponuka, ktorá pomáha zákazníkovi robit’ jej/jeho prácu efektívnejšie, výhodnejšie, alebo za rozumnejšiu cenu ako prípadná alternatíva.

2. Druhým elementom je vzorec zisku, tvorený z príjmovej a nákladovej štruktúry, ktorý špecifikuje ako spoločnost' generuje zisk a potrebnú hotovost' pre zamýšl'ané operácie. 
3. Tretím elementom sú zdroje - ako zamestnanci, zákazníci, technológie, produkty, zariadenia a hotovost' - ktoré prinášajú zákazníkovi hodnotu.

4. Posledným, štvrtým elementom sú procesy ako výroba, vývoj a výskum, rozpočet a predaj Christensen et al (2011).

Za správnych okolností môže byt' jeden z elementov - zdroje - vyňatý zo získanej spoločnosti a vložený do rodičovského obchodného modelu. Taký postup je možný, pretože zdroje môžu existovat' oddelene od spoločnosti (firma môže zaniknút' už zajtra, ale zdroje budú stále existovat'). Autori nazývajú tento druh obchodu akvizície napomáhanie obchodnému modelu - leverage my business model (LBM).

Spoločnost' však nemôže rutinne vložit' ostatné elementy z akvizičného obchodného modelu do vlastnej spoločnosti, alebo naopak. Vzorec zisku a procesy nemôžu existovat' oddelene od organizácie a asi by, dokonca, ani neprežili odlúčenie od spoločnosti. Firma môže kúpit' iný obchodný model, fungovat' $\mathrm{s}$ ním oddelene a používat' ho ako platformu pre transformačný rast. Tento model autori nazývajú akvizícia „vylepšenie (reinvencia) obchodného modelu - reinvent my business model (RBM).

Manažéri zvyknú verit', že spoločnosti môžu dosiahnut' mimoriadnu návratnost' práve kúpou zdrojov inej spoločnosti a lacnejšie. Alternatívne odchádzajú od potenciálne-tranformačného obchodu v mylnej predstave, že akvizícia je nadhodnotená, alebo zničia hodnotu vysokorastového obchodného modelu snahou integrovat' spoločnost' do ich vlastného obchodného modelu. Takéto chyby sú najmä rozšírené pri cezhraničných fúziách a akvizíciách, kde možnosti hlbokého poznania ciel'ovej spoločnosti je relatívne obmedzená kultúrne a geograficky. Je možné sa vyhnút' spomínaným bežným chybám? Áno. A to prostredníctvom porozumenia nasledovných možností:

- zvýšenie firemnej výkonnosti

- reinvencia obchodného modelu (Christensen et al, 2011).

V prvom prípade, základnou úlohou manažéra je dodat' očakávané výsledky investorom v krátkodobom horizonte a to prostredníctvom efektívnej operácie. Spoločnosti majú tendenciu preferovat' akvizície na základe obchodného modelu LBM, aby si rýchlejšie zlepšili ich ziskový vzorec. Potom vzorec umožňuje novej entite určovat' vyššie ceny alebo redukovat' náklady.

Autori tiež tvrdia, že poslaním ich teórie je upútat' pozornost' manažérov na akvizície pomocou vylepšením obchodného modelu RBM, ktoré zabezpečujú základy pre dlhodobý rast. Vychádzajúc $\mathrm{z}$ toho, že hodnoty existujúceho obchodného modelu časom stratia na konkurencieschopnosti a technologickom vybavení, vždy tu vzniká nepríjemná možnost' rozkladania ich ziskového potenciálu. Sú to však akvizície RBM modelu, ktoré pomôžu manažérom prekonat' túto prekážku. Adopcia tohto spôsobu akvizície úplne prerobí spoločnost' a nastaví trajektóriu dlhodobého rastu. Akvizície typu RBM najúčinnejšie zvyšujú sadzbu na vytváranie hodnoty pre akcionárov. Je paradoxné, že nadobúdatelia zvyčajne nedoplatia akvizície typu RBM, ale preplatia akvizície typu LBM. Teória nám tiež poskytuje niekol'ko typov ako sa vyhnút' integračným omylom. Odpoved' na otázku znova smeruje k uvedomeniu si typu akvizície. Ak kupujete spoločnost' s ciel'om zvýšit' si firemnú výkonnost', mali by ste premiestnit' zdroje do svojej spoločnosti. Ale ak si kupujete podnik kvôli jeho obchodnému modelu, je dôležité si ho držat' nedotknutý a vykonávat' činnosti oddelene (Christensen et al, 2011). 
Jednou z výhod uplatňovania manažmentu znalostí v medzinárodných fúziách a akvizíciách je to, že má „tendenciu zvyšovat' výkonnost' organizácie pomocou využitia existujúcich znalostných aktív“" (Jasimuddin, 2012). V tejto súvislosti prichádza k lepšiemu využívaniu firemných znalostí, čo môže firme zabezpečit' dostupnost' „správnych znalostí správnym l'ud’om v správny čas“" (Jasimuddin, 2012). Ďalšími výhodami, ktoré vyplývajú z uplatňovania manažmentu znalostí v organizácii je možnost' „vytvárania nových nápadov, lepšie využitie organizačnej moci myslenia, podpory inovácií, zachytávania nových postrehov a skúsenosti, aby boli k dispozícii vtedy, kedy, kde a kým budú požadované“. Počas fúzie alebo akvizície môže príst' ku strate podnikových zdrojov - znalostí, najčastejšie vedci varujú pred stratou tacitných znalostí, ktoré sú budované na skúsenostiach l’udí v organizáciách. Kupujúca spoločnost' musí zvládnut' podchytenie znalostí počas zmien v organizačnej štruktúre a kultúre (Jasimuddin, 2012). Manažment znalostí je rozhodujúcim elementom pre úspešné procesy v oblasti fúzií a akvizícií, ako i v riadení znalostí získaných z oboch skombinovaných podnikatel'ských jednotiek za účelom vytvorenia hodnoty. Výzva pre akvizičných manažérov, či už explicitná alebo implicitná je, aby začali brat' vážne riadenie znalostných aktív a kreatívne využitie a rozvíjanie komunikačných vzorov.

Ak sa pozrieme na modely LBM a RBM optikou znalostného manažmentu, môžeme konštatovat', že jeho okamžitá a správna aplikácia v integrácii je podmienkou úspechu modelov LBM. Pri modeloch RBM jeho aplikácia môže trvat' určitý čas vzhl'adom na „transplantáciu“ obchodného modelu, ale z dlhodobého hl'adiska je taktiež nevyhnutnost'ou. V tomto kontexte vidíme potrebu presadenia nového pohl'adu na cezhraničné fúzie a akvizície ako na komplexný jav zahŕnajúci nielen ekonomické ukazovatele a hodnoty. Tým chceme povedat', že reštrukturalizačné integračné procesy smerujúce k rôznym kombináciám integrovaných podnikov a organizácií musia brat' do úvahy aj kultúrne, humánne a humanitárne faktory, ak by mali byt' úspešné v zmysle očakávaných ekonomických synergií. V tejto súvislosti tiež vidíme potrebu venovania vel'kej pozornosti príčinám zlyhania akvizičných procesov. Samozrejme, existuje rozsiahla literatúra k tejto otázke, ale podl'a nášho názoru, nedostatočne prízvukuje nutnost' zachovania unikátnych schopností zlučovaných podnikov, vrátane ich hodnotných a väčších zákazníkov. Tiež existujúce analýzy primálo zdôrazňujú, že prišla doba, ked' znalosti a manažment znalostí nie sú módnymi výstrelkami, ale praktickou nutnost'ou. Okrem toho, je potrebné prehodnotit' spoločensko-ekonomické stereotypy priemyselnej spoločnosti a stotožnit' sa s novými hodnotami a ukazovatel'mi ekonomickej úspešnosti, z ktorých viaceré tzv. „nehmotné“ ukazovatele sa tak často stále podceňujú. Domnievame sa, že je potrebné resuscitovat' váhu individuálneho subjektu a lídra v ekonomických procesoch, vrátane akvizičných, lebo manažment znalostí nepredpokladá vytvorenie anonymných „skrutiek“, ale zodpovedných a tvorivých aktérov bez ohl'adu na to, aké miesto v podnikovej hierarchii zastávajú. V tejto súvislosti zdôrazňujeme, že manažment znalostí je inšpiráciou $\mathrm{k}$ opusteniu tradičných vertikálnych línií zodpovednosti a vedie $\mathrm{k}$ horizontálnej demokratickej spolupráci a výpomoci vo všetkých etapách podnikových procesov.

\section{3 Ďalšie odporúčania a záver}

Prirodzene, menší alebo väčší príspevok k problematike by nemal cenu, ak by sme nenačrtli našu víziu uplatnenia znalostného manažmentu $\mathrm{v}$ praxi akvizičných manažérov. Pri cezhraničných fúziách a akvizíciách považujeme za potrebné:

1. nepodceňovat' predintegračné analýzy a jednania a brat' ich ako organickú súčast' rekombinačných procesov; 
2. správne vytypovat' l'udské zdroje v nadobúdaných podnikoch, ktoré doslova zosobňujú tacitné znalosti tak často podceňované manažérmi, ktorí nevyužívajú princípy manažmentu znalostí;

3. udržat' tieto l'udské zdroje a ,pretavit“" tacitné znalosti z jednej a druhej firmy $\mathrm{v}$ integrovanej podobe (,,best of both“ prístup k integrácii) vo novej jednotky

4. v poakvizičnom období neúnavne pracovat' na budovaní novej spoločnej podnikovej kultúry otvorenosti, spolupráce a zohl’adnenia záujmov širšieho spoločenského kontextu.

$\mathrm{Na}$ úplne praktickej úrovni navrhujeme pri uskutočňovaní fúzií alebo akvizícií vypracovat' „Manuál akvizičného manažéra“" vychádzajúci z princípov manažmentu znalostí, kde by stručne a prehl'adne boli vymenované neodmyslitel'né kroky a opatrenia vo všetkých fázach integračného procesu. Súčast'ou takého návodu by boli v neposlednom rade tzv. áno/nie integračných cezhraničných aktivít. Napríklad, akvizícia nemusí splnit' očakávania, pretože akviziční manažéri vytypovali partnera, ktorý je nekompatibilný z hl'adiska strategického ciel'a podnikania alebo $\mathrm{v}$ akvizičnej štúdii chýbajú podstatné prvky zabezpečenia manažmentu znalostí atd'. Varovania takého druhu by mohli predíst' chybám zo „zanedbania“, ku ktorým tak často dochádza v predintegračnej horúčke, integračnej zaneprázdnenosti a pointegračnej únave a uspokojenosti. Ked’ ide o predintegračnú horúčku, tak úlohou manuálu by mala byt' výzva $\mathrm{k}$ dôslednej práci, ktorá predchádza začiatku vlastných jednaní. Základnou východiskovou myšlienkou takého manuálu by mala byt' aj trpezlivost' a dôslednost' $\mathrm{v}$ priebehu celého procesu namiesto obvyklého náhlenia sa ku koncu. Všeobecne, takýto manuál by mohol prispiet' k prízvukovaniu myšlienky, že je na čase, aby si súčasné ekonómie a ekonomiky začali všímat' nielen výsledky (vel'mi často zjednodušene chápané ako krátkodobé zisky), ale aj procesy, ktoré sú formou l’udského snaženia a spolunažívania, čím získavajú hodnotu ako také. V tomto kontexte $\mathrm{v}$ „Manuáli akvizičného manažéra“ by nemal chýbat' aj zoznam prekážok, ktoré by opodstatnili rozhodnutie o možnom odstúpení od konkrétnej kombinácie. Ďalšie upozornenie príručky by sa mohlo týkat' prevedenia strategického zámeru do kritérií pre vyhl'adávanie a výber partnera. Inak povedané, akviziční manažéri musia mat' úplne jasno v tom, čo chcú nájst' v ciel’ovej firme. Ak nezhody ohl'adne takýchto kritérií nie sú riadne určené, budú sa niest' celým akvizičným a aj poakvizičným procesom. Očividne, manuál musí prízvukovat' rozšírenú due diligence, ktorá by zahrňovala hodnotenie kompatibility správania tímov a ich kultúrne hodnoty. (Pre cezhraničné integračné procesy to je nesmierne dôležité). Táto úroveň due diligence je totiž schopná odhalit' širokú škálu potenciálnych obchodných a kultúrnych prekážok na ceste $\mathrm{k}$ integračnému úspechu. $\mathrm{V}$ manuáli by tiež nemali chýbat' upozornenia na to, ako je dôležité definovat' očakávaný „konečný stav“ zlúčenia. Očividne, že do určitej miery tento stav je predvídaný, ked' sa dohoda štruktúruje. Avšak, je tu d'alšia potreba definovat' operačné vzt'ahy, širšie oblasti integrácie a ich implikácie pre riadenie. Treba mat' na zreteli, že podniková integrácia nemusí byt' o úplnom zlúčení alebo o úplne oddelenej činnosti. Existuje celý rad medzistavov. Každopádne, akvizičný manažér by mal byt' upozornený, že rozhodnutia o vybudovaní operačného vzt'ahu medzi spoločnost’ami by nemali vychádzat' jedine z úvah o moci alebo kontrole, čo je často prípadom pri zlúčení podnikov vyspelých a menej vyspelých krajín. Ciel'om integrácie je v prvom rade vytvorenie synergií a hodnoty (Vícenová, 2013) Dosiahnutie dobrého postintegračného spojenia sa často chápe ako vec náhody, št'astia, priaznivých vonkajších podmienok. Ciel'om manuálu by malo byt' prekonanie tohto názoru a upozornenie na dôležitost' „l'udského faktoru“ v integračných procesoch. K tomu môže prispiet' aj akýsi „imperatív“ zahrnutý do manuálu. Tento by vyzýval k rozšíreniu procesu due diligence, tak aby zahŕňal otázky kultúrnej vhodnosti zlučovaných podnikov; širšiemu privolaniu a uplatneniu profesionálov z oblasti l'udských zdrojov; uskutočneniu kultúrnych auditov pred začiatkom pozmeňujúcich manažérskych iniciatív; 
rozsiahlejšej komunikácii a zapojeniu pracovníkov na všetkých úrovniach integračného procesu; k spravodlivejšiemu a objektívnejšiemu reselektovaniu l'udí na pozície v novom podniku a rozdeleniu rolí. Imperatív tiež upozorní na dôležitost' širokej účasti $\mathrm{v} d u e$ diligence; a zabezpečí psychologickú prípravu l'udí cestou seminárov a besied. Komunikačné plány nesmú zabudnút', že sa týkajú všetkých zainteresovaných, a to zákazníkov, dodávatel'ov, zamestnancov, a predstavitel'ov širšej komunity. Určenie najpálčivejších problémov, ktoré potrebujú okamžité riešenia, je tiež dôležité. Myšlienky manažmentu znalostí nie sú úplne cudzie pre širšiu ekonomickú komunitu na Slovensku, a tak jemnejšie diferencovaný prístup k ponímaniu akvizícií a fúzií sa pomaly stáva aj záležitost'ou praxe. Napríklad, pri fúziách a akvizíciách nejde už len o "výhodnú cenu", ale aj o odpovede na otázky týkajúce sa kultúrno-spoločenského kontextu integračného procesu. Akviziční manažéri vyhl'adávajú ciel'ové podniky majúc pred sebou jasnú predstavu či spoločnosti ide o prežitie, o zlepšenie existujúcej činnosti prodstredníctvom akvizície alebo o dramatickú premenu spoločností na rastovú. V prvom prípade ide o zachovanie predošlej trajektórie, kým $\mathrm{v}$ druhom o základné presmerovanie spoločnosti. Inými slovami už nie je ničím výnimočným, ked' sa v akvizičných aktivitách uvažuje o nadobúdanej spoločnosti v zmysle ciel'ového obchodného modelu. Akviziční manažéri si začínajú byt' plne vedomí štyroch elementov obchodného modelu, ktoré potenciálne vytvárajú hodnotu, a tak ešte pred akvizíciou plánujú ich možnú rekombináciu, alebo dokonca vyňatie zo získanej spoločnosti a vloženie do rodičovského obchodného modelu.

\section{Literatúra}

[1] BALÁŽ, P., S. FERENČÍKOVÁ, J. FILIP, V. GAVAL'OVÁ, P. KNAPÍK, L'. PAVELKA, I. POLIAČIK, B. ŠAKOVÁ, D. ŠÍBL a O. ZORKÓCIOVÁ, 2005. Medzinárodné podnikanie. 4. vyd. Bratislava: SPRINT. ISBN 80-89085-51-2.

[2] BUREŠ, V., 2007. Znalostní management a proces jeho zavádění. Průvodce pro praxi. 1.vyd. Praha: Grada Publishing, a.s. ISBN 978-80-247-1978-8.

[3] FERENČÍKOVÁ, S., A. PAPPOVÁ, T. HLUŠKOVÁ, A. VÍCENOVÁ, D. KRAJČÍK, S. FERENČÍKOVÁ a J. PÁZSTOROVÁ, 2013. Medzinárodná expanzia firiem: stratégie, partnerstvá a l'udské zdroje. 1. vyd. Bratislava: Vydavatel'stvo IURA EDITION. ISBN 978-80-8078-532-1.

[4] HVORECKÝ, J., 2013. Compability of Knowledge. In: Konferencia Enterprise and Competitive Environment. Brno: Mendelova univerzita. ISBN 978-80-87106-64-8.

[5] HVORECKÝ, J. a B. LICHARDUS, 2012. Rationality and Irrationality in Knowledge Management. In: L. VÁRKOLY a R. SZCZEBIOT, eds. Present Days of Innovations. Łomža: The State Higher School of Computer Science and Business Administration, p. 34-39. ISBN 978-83-60571-23-1.

[6] CHRISTEnSEN, C. M., R. ALTON, C. RISING a A. WALDECK, 2011. The New M\&A Playbook. Harvard Business Review. March 2011, 49-57. ISSN 0017-8012.

[7] JASIMUDDIN, S. M., D. FAULKNER, S. TEERIKANGAS a R. J. JOSEPH, 2012. The Handbook of Mergers and Acquisitions. Kap. 18. Knowledge Management in Mergers and Acquisitions. UK: Oxford University Press. ISBN 978-0-19-960146-2.

[8] KELEMEN, J., P. BERKA, V. BUREŠ, J. HORÁKOVÁ, J. HVORECKÝ a P. MIKULECKÝ, 2007. Pozvanie do znalostnej spoločnosti. $1 . \quad$ vyd. Bratislava: Vydavatel'stvo IURA EDITION. ISBN 978-80-8078-149-1. 
[9] MIKLOŠÍK, A., E. HVIZOVÁ a Š. ŽÁK, 2012. Znalostný manažment ako podstatný determinant udržatel'nosti konkurencieschopnosti podniku. Ekonomický časopis, 60(10), 1041-1058. ISSN 0013-3035.

[10] MLÁDKOVÁ, L., 2005. Moderni prístupy $k$ managementu Tacitní znalost a jak ji řídit. 1. vyd. Praha: C. H. Beck. ISBN 978-80-7179-310-8.

[11] SPODNIAK, J. a M. CESNAK, 2010. Fúzie a akvizície: Bežná súčast’ rastovej stratégie spoločností po celom svete [online]. [cit. 20. októbra 2013]. Dostupné z: http://www.investujeme.sk/fuzie-a-akvizicie-bezna-sucast-rastovej-strategie-spolocnostipo-celom-svete/

[12] STAHL, G. K. a M. E. MENDENHALL, 2005. Mergers and acquisitions Managing Culture and Human Resources. Stanford: Stanford University Press. ISBN 978-0-80474661-3.

[13] ŠAKOVÁ, B., 2004. Transnacionálne korporácie vo svetovej ekonomike. Bratislava: Ekonóm. ISBN 80-225-1889-1.

[14] TRUNEČEK, J., 2004. Management znalostí. 1. vyd. Praha: C. H. Beck. ISBN 80-7179884-3.

[15] VÍCENOVÁ, A., 2013. Manažment znalostí v medzinárodných fúziách a akvizíciách. Doktorandská dizertačná práca. Bratislava: VŠM. 